Jurnal Bosaparis: Pendidikan Kesejahteraan Keluarga

Volume 9, Nomor 2, Juli 2018

\title{
SUBSTITUSI TEPUNG TALAS KIMPUL MENJADI KUE KERING SAGON
}

\author{
Desak Nyoman Kartika Dewi, Damiati, Cokorda Istri Raka Marsiti \\ Jurusan Pendidikan Kesejahtraan Keluarga \\ Universitas Pendidikan Ganesha \\ Singaraja, Indonesia \\ e-mail: desakkartikadewi@yahoo.com,damiati@undiksha.ac.id, \\ raka.marsiti@undiksha.ac.id
}

\begin{abstract}
Abstrak
Penelitian ini bertujuan untuk mengetahui kualitas kue kering sagon dengan mengunakan tepung talas kimpul dilihat dari aspek (1) rasa,(2) warna dan (3) tekstur. Panelis dalam penelitian ini menggunakan panelis terlatih yang terdiri dari 25 orang panelis terlatih. Metode pengumpulan data yang digunakan dalam penelitian ini yaitu metode observasi dengan menggunakan instrument berupa lembar uji organoleptik dengan 3 tingkatan yaitu baik, cukup, kurang. Data dianalisis dengan menggunakan teknik deskriptif kuantitatif. Hasil penelitian ini menunjukkan (1) Kualitas kue kering sagon mengunakan tepung talas kimpul dilihat dari aspek rasa berada dalam kategori baik $(2,76)$,sesuai tolok ukur yaitu manis dan gurih,(2)Kualitas kue kering sagon mengunakan tepung talas kimpul dilihat dari aspek warna berada dalam kategori baik $(2,68)$ sesuai tolok ukur yaitu dominan memiliki putih kecoklatan sesuai dengan warna dari tepung talas kimpul, (3) Kualitas kue kering sagon mengunakan tepung talas kimpul dilihat dari aspek tekstur berada dalam kategori baik $(2,56)$, sesuai tolok ukur yaitu kering dan renyah.
\end{abstract}

Kata Kunci: Tepung talas kimpul, tekstur, rasa, sagon, warna

\begin{abstract}
This study aims to determine the quality of sago cake by using taro flour seen from aspects (1) flavor, (2) color and (3) texture. Panelists in this study used trained panelists consisting of 25 trained panelists. Data collection method used in this research is the method of observation by using instrument in the form of organoleptic test sheet with 3 levels that is good, enough, less. Data were analyzed by using quantitative descriptive technique. The result of this research shows (1) The quality of the sago cake using taro flour is seen from the taste aspect is in good category (2.76), according to the benchmark that is sweet and savory, (2) The quality of sagon cake using taro flour seen from aspect of color is in good category $(2,68)$ according to benchmark that is dominant have white brown in accordance with color of taro flour, (3) Quality of sagon cake using flour taro kimpul seen from aspect of texture is in good category (2,56), according to the benchmark that is dry and crunchy.
\end{abstract}

Keywords: Taro, flour, texture, flavor, sagon, color 
Jurnal Bosaparis: Pendidikan Kesejahteraan Keluarga

Volume 9, Nomor 2, Juli 2018

\section{PENDAHULUAN}

Kabupaten Buleleng merupakan salah satu kabupaten yang terletak dibagian Utara Pulau Bali, Buleleng merupakan daerah yang memiliki lahan pertanian dan perkebunan yang cukup luas, seperti umbiumbian, padi-padian, sayur-sayuran,dan buah-buahan yang dimanfaatkan masyarakatnya untuk dikonsumsi sendiri atau diperjual belikan untuk memenuhi kebutuhan sehari-hari. Salah satu hasil perkebunan seperti umbi-umbian adalah salah satu bahan makanan yang memiliki banyak manfaat. Salah satu jenis umbi yang dimanfaatkan adalah talas. Talas merupakan tanaman asli daerah tropis yang juga sebagai sumber pangan yang penting karena selain mengandung sumber karbohidrat juga mengandung protein dan lemak, serta mengandung beberapa unsur mineral dan vitamin (Cahya,2014). Jenis jenis talas diantaranya talas bogor, talas padang, talas kimpul, talas jepang, dan beberapa jenis talas lainnya, jenis talas yang digunakan peneliti adalah talas kimpul.
Talas kimpul dalam Bahasa Bali dikenal dengan sebutan Keladi. Sedangkan dalam bahasa latin talas kimpul disebut dengan Xanthosoma Sagitifolium. Talas kimpul merupakan tumbuhan yang tumbuh didaerah tropis, yang banyak tumbuh di ladang maupun perkebunan warga. Sampai saat ini, produk hasil olahan talas kimpul masih jarang ditemui. Pada umumnya talas kimpul hanya diolah dengan cara direbus, dikukus, digoreng atau dijadikan keripik (Widayanti,2001). Hal ini berdampak pada talas kimpul yang hanya memiliki nilai ekonomis yang masih rendah. Jarangnya pemanfaatan talas kimpul ini dikarenakan masyarakat yang lebih mengenal talas kimpul dengan bahan makanan yang memiliki rasa gatal yang diakibatkan oleh senyawa yang terkandung dalam umbi talas kimpul (Cahya,2014). Talas kimpul memiliki keunggulan dari kandungan mineral, serat dan karbohidrat.

Tabel 05:

Kandungan gizi talas kimpul

\begin{tabular}{ll}
\hline Komponen & Kandungan \\
\hline Air & $67,10 \%$ \\
Protein & $1,55 \%$ \\
Lemak & $0,44 \%$ \\
Pati & $27,6 \%$ \\
Gula & $0,42 \%$ \\
Serat makanan & $0,99 \%$ \\
Vitamin C mg/100gr & $13,60 \mathrm{gr}$ \\
Abu & $1,04 \%$ \\
\hline
\end{tabular}

Sumber : Bramtarades (2013)

Talas kimpul jika dilihat dari segi ekonomisnya, memiliki peluang yang besar, ini dapat dilihat dari harga talas kimpul yang terjangkau murah, dan mudah diperoleh. Hal ini dikarenakan talas kimpul bukan merupakan tanaman musiman sehingga kesediannya mudah diperoleh. Selain itu talas kimpul juga tidak membutuhkan waktu yang lama untuk menghasilkan umbi, karena talas kimpul memiliki masa panen sekitar 7 - 10 bulan setelah masa tanam, jika tumbuh subur talas kimpul akan tumbuh subur dengan mencapai 1 hingga 1,5 meter, dengan batang yang bergetah (Hilmi,2014).. 
Talas kimpul merupakan tanaman yang tidak tahan lama dalam kondisi segar, mudah rusak apabila tidak segera diolah. Maka dari itu, untuk meningkatkan kualitas dan daya simpan talas kimpul maka peneliti akan mengolah talas kimpul menjadi tepung yang bertujuan untuk meningkatkan daya simpan dan meningkatkan nilai ekonomis dari talas kimpul. Berdasarkan hasil observasi awal dilakukan oleh peneliti di Pasar Banyuatis pada hari sabtu tanggal 11 Maret 2017, harga jual talas kimpul berkisar antara $R p 2.000,00$ sampai $R p$ $2.500,00$ per kilogram. Selain memiliki harga yang murah talas kimpul juga merupakan tanaman tidak tahan lama apabila tidak segera diolah, maka dari itu untuk meningkatkan kualitas dan daya simpan dari talas kimpul peneliti mengolah talas kimpul menjadi tepung yang bertujuan untuk meningkatkan daya simpan dan untuk meningkatkan nilai ekonomis dari talas kimpul.

Tepung talas kimpul merupakan tepung yang dihasilkan dari umbi talas kimpul yang sudah memalui proses penjemuran atau pengeringan yang bertujuan untuk menurunkan kadar air dari talas kimpul (Pratama \& Nisa, 2014). Tahapan proses pembuatan tepung talas kimpul yaitu pertama dengan mengupas dan memotong talas kimpul, yang kemudian di potong dan diparut kasar,kemudian direndam dengan larutan air garam kurang lebih selama 30 menit, yang kemudian dicuci kembali untuk menghilangkan bekas air garam, kemudian dijemur hingga kering sebelum digiling halus. Beberapa contoh dalam penelitian sebelumnya talas sudah dimanfaatkan menjadi tepung yang diolah untuk menghasilkan produk yang memiliki nilai jual tinggi yang dilakukan oleh I Gusti Putu Bayu Bramtadares mahasiswa jurusan Ilmu dan Teknologi Pangan, mengolah Talas kimpul tepung diformulasikan dengan tepung terigu dalam pembuatan Roti Tawar, Pemanfaatan tepung talas kimpul menjadi bahan dasar dalam pembuatan cookies oleh Nurani dkk, dalam Jurnal Teknologi Hasil Pertanian Universitas Brawijaya (2014),Formulasi Mie Kering dengan Substitusi Tepung Kimpul oleh Pratama dkk dalam Jurnal Pangan dan Agroindustri (2014). Tahap pembuatan tepung talas kimpul yaitu dengan mengupas talas kimpul kemudian mengiris tipis - tipis kemudian dijemur hingga kering. Setelah benar - benar kering kemudian talas kimpul digiling hingga menjadi bubuk halus, kemudian dijemur kembali agar tepung lebih tahan lama selama penyimpanan.

Berdasarkan hasil pra eksperimen yang dilakukan peneliti dalam $1 \mathrm{~kg}$ talas kimpul akan memperoleh tepung sekitar 600-700 gram tepung talas. Beberapa kandungan yang terdapat pada tepung ketan juga terdapat pada tepung talas seperti kandungan karbohidrat, protein, air, abu, lemak, pati.

Tabel 02 :

Kandungan Gizi Tepung Talas Kimpul dan Tepung Ketan per 100 gram No Komponen Tepung Tepung ketan talas

\begin{tabular}{lccc}
\hline 1 & Air & $12,80 \%$ & $17,70 \%$ \\
2 & Abu & $9,13 \%$ & $0,25 \%$ \\
3 & Protein & $6,55 \%$ & $10,34 \%$ \\
4 & Lemak & $2,62 \%$ & $3,16 \%$ \\
5 & Karbohidrat & $68,90 \%$ & $68,58 \%$ \\
6 & Pati & $5,60 \%$ & $5,37 \%$
\end{tabular}

Sumber. Hasil Analisis Labolatorium Undiversitas Udayana (2017) 
Menurut penulis yang juga sebagai peneliti, tepung talas kimpul cocok digunakan dalam pembuatan kue kering yang di substitusikan dengan tepung ketan, karena beberapa kandungan yang terdapat dalam tepung ketan juga terdapat pada tepung talas kimpul seperti kandungan air, abu, protein, lemak, karbohidrat, pati dan amilo pektin, sehingga cocok untuk disubstitusikan dalam pembuatan kue kering sagon.

Sagon merupakan kue kering tradisional yang memiliki daya tahan lama dan cukup popular di Bali. Tidak hanya di Bali sagon juga popular di pulau Jawa dan Sumatera. Sagon pada umumnya terbuat dari tepung ketan, kelapa yang disangrai,, gula pasir, dan garam memiliki banyak variasi bentuk yang berbeda, yang dibuat sesuai selera dari pembuatnya, tetapi pada intinya sagon memiliki rasa yang manis dan gurih serta aroma yang khas karena terbuat dari bahan dasar kelapa dan tepung ketan. Secara umum sagon memiliki dua jenis, yaitu sagon yang bertekstur basah dan sagon yang bertekstur kering.

Dari segi pembuatan sagon basah dan sagon kering memiliki persamaan dari segi bahan yang digunakan, dan memiliki perbedaan dalam proses tehnik pengolah dan daya simpan dari kedua jenis sagon ini. Sagon biasanya digunakan sebagi bahan cemilan dan khususnya untuk masyarakat di Bali sagon biasanya digunakan dalam pelengkap dalam saran pembuatan atau sesajen banten. Menurut survey pasar yang dilakukan peneliti di pasar Banyuatis pada tanggal 30 maret 2017 sampai tanggal 4 April 2017, penjualan sagon meningkat ketika hari raya Galungan dan Kuningan. Hal ini disebabkan karena menurut masyarakat sagon merupakan jajanan tradisional yang wajib diisi dalam pembuatan banten, selain itu karena harganya murah dan miliki tekstur yang kering dan rasa yang manis maka sagon banyak diminati oleh masyarakat disemua kalangan.

Substitusi produk sagon berbahan tepung talas kimpul merupakan salah satu cara untuk meningkatkan bahan baku lokal dan meningkatkan nilai ekonomis dari talas kimpul serta menambah keanekaragaman jajanan atau kue dengan mengunakan bahan utama yang berbeda, dalam penelitian ini peneliti memilih sagon kering sebagai bahan penelitian karena sagon kering memiliki nilai jual yang lebih tinggi dibandingkan dengan sagon basah karena sagon kering memiliki daya simpan yang lebih lama dibandingkan sagon basah. Tehnik pembuatan kue kering sagon berbahan tepung talas kimpul tidak jauh berbeda dari pembuatan sagon biasa, hanya saja bahan utama sagon yang dengan mengunakan tepung ketan sebagian bahannya digantikan dengan tepung talas kimpul tetapi untuk penggunaan bahan lain masih sama seperti menggunakan kelapa yang di sangrai, gula pasir yang dicairkan, dan garam,sehingga dalam penelitian ini sagon dengan tepung talas diharapkan memiliki kualitas yang baik, serta memiliki tekstur yang sesuai, dengan rasa yang manis dan gurih. Berdasarkan permasalahan mengenai pemanfaatan talas kimpul maka peneliti mengangkat judul penelitian substitusi tepung talas kimpul menjadi kue kering sagon.

\section{METODE PENELITIAN}

Jenis $\begin{gathered}\text { penelitian ini } \\ \text { pensperimen. }\end{gathered} \begin{array}{r}\text { adalah } \\ \text { Penelitian } \\ \text { eksperimen adalah suatu metode }\end{array}$
penelitian untuk mengadakan kegiatan
percobaan guna mendapatkan suatu hasil.
Penelitian ini dilakukan dengan
memanfaatkan tepung talas kimpul
menjadi sagon yang disubstitusikan
dengan menggunakan dua formulasi
bahan utama yaitu tepung talas kimpul
dengan tepung ketan, uji coba pertama
dengan menggunakan perbandingan $75 \%$


tepung tal as kimpul dan 25\% tepung ketan, hasil sagon yang diproleh terlalu rapuh dan tidak bisa dibentuk karena terkstur tepung talas yang terlalu kering. Kemudian uji coba kedua yaitu 50\% tepung talas kimpul dan $50 \%$ tepung ketan, dan formulasi bahan lain masih tetap sama, hasil yang lebih bagus dan sagon dihasilakan lebih baik, maka dari itu penelitian dilakukan dengan menggunakan perbandingan bahan 1:1 atau dengan perbandingan $50 \%$. Resep yang digunakan dengan acuan didalam pembuatan sagon dengan menggunakan tepung ketan.

Prosedur kerja dalam eksperimen pembuatan kue kering sagon dengan substitusi tepung talas kimpul.

\section{Tahap Persiapan}

Tahap persiapan merupakan persiapan yang harus dilakukan sebelum melakukan suatu proses. Didalam tahap persiapan ini yang dipersiapkan adalah bahan dan alat yang akan digunakan dalam pembuatan sagon dari tepung talas kimpul seperti pada persiapan bahan, harus memperhatikan pemilihan tepung talas kimpul dan tepung ketan yang masih dalam kondisi bagus, tidak berbau apek dan dalam kondisi kering, selain itu pemilihan bahan lain seperti kelapa, gula pasir dan garam juga harus dipilih dari bahan yang masih memiiki kualitas bagus. Setelah memperoleh bahan kemudian ditimbang sesuai dengan resep yang akan digunakan sehingga sesuai dengan hasil yang diharapkan. Sedangkan peralatan yang digunakan dalam proses pembuatan seperti: Waskom, parutan, wajan, sendok kayu, timbangan, mangkok kecil, gelas ukur, dan loyang.

\section{Tahap Pengolahan}

Proses pembuatan sagon tepung talas kimpul menggunakan resep standar tepung ketan. Adapun langkah yang dilakukan dalam proses pembuatan sagon tepung talas kimpul yaitu dengan menyanggri kelapa parut yang bertujuan untuk meningkatkan aroma dari sagon dan tepung ketan terlebih dahulu kemudian mencairkan gula pasir lalu mencampur semua bahan hingga rata, dan setelah itu adonan di bentuk dan dioven dengan suhu $150^{\circ} \mathrm{C}$ selama 25 menit hingga kue kering dan matang, dan di dinginkan.

3. Tahap Penyajian

Tahap penyajian yaitu tahap akhir dalam suatu penelitian dimana tahap penyajian ini merupakan perlakuan terhadap makanan atau bahan pangan yang sudah diolah atau belum dioalah, untuk menjaga kualitas dari makanan sebelum sampai ketangan konsumen. Dalam penelitian ini penyajian sagon menggunakan toples kaca yang tertutup agar kualitas sagon tetap terjaga.

Lokasi penelitian dilakukan di

Labortorium Tata Boga Jurusan Pendidikan Kesejahtraan Keluarga, Fakultas Teknik dan Kejuruan, Universitas Pendidikan Ganesha Singaraja dan di Laboratorium Fakultas Pertanian Univesitas Udayana. Variable adalah objek penelitian atau gejala dari suatu objek yang menjadi titik perhatian suati penelitian (Arikunto,2002), variabel dalam penelitian ini adalah kualitas sagon tepung talas kimpul dari aspek rasa, warna, dan tekstur. Metode pengumpulan data dalam penelitian ini mengunakan metode observasi atau pengamatan yang mengunakan bantuan alat indra manusia, dengan mengunkan uji oraganileptik untuk mengetahui kualitas dari sagon yang terbuat dari tepung talas kimpul dari aspek rasa,warna, dan tekstur. Uji organoleptik yang digunakan dalam penelitian adalah mutu hedonik. Dalam mutu hedonik panelis diminta untuk memberikan tanggapan pribadi tentang kesan baik atau buruk dari hasil penelitian. Panelis terpilih adalah panelis terlatih yang terdiri dari 15-25 orang. Dalam penelitian ini panelis digunakan sebanyak 25 orang yang terdiri dari 5 orang dosen PKK Tata Boga, 1 orang Laboran, 9 orang mahasiswa PKK Program Studi Tata Boga, 4 orang Guru Tata Boga SMK Negeri 1 Seririt, dan 6 orang Guru Tata Boga SMK Pariwisata Triatma Jaya Singaraja. 
Pada instrumen ini skala mutu hedonik yang digunakan mengunakan tiga tingkatan. Skor yang diberikan pada setiap panelis yaitu: 1. Kurang, 2. Cukup, 3. Baik, serta dapat diaplikasikan dalam skala numberik pada tabel seperti berikut ini:

Tabel 03 :

Skala Mutu Hedonik dan Skala Numerik Uji Kualitas Sagon Tepung Talas Kimpul

\begin{tabular}{cc}
\hline Skala Mutu Hedonik & Skala Numberik \\
\hline Baik & 3 \\
Cukup & 2 \\
Kurang & 1 \\
\hline
\end{tabular}

Instrument yang digunakan dalam penelitian ini berupa lembar uji kualitas yang memuat tolok ukur akan diberikan pada setiap panelis untuk menilai kualitas terhadap suatu produk yang disajikan oleh peneliti sebagai berikut:

Tabel 04 :

Lembar Penilaian Untuk Uji Kualitas Terhadap Sagon Tepung Talas Kimpul

Aspek Penilaian Sagon dari Teoung Talas kimpul A

$3 \quad 2$

B

\begin{tabular}{lllllll} 
& 3 & 2 & 1 & 3 & 2 & 1 \\
\hline Rasa & & & & & & \\
Warna & & & & & & \\
Tekstur & & & & & \\
\hline
\end{tabular}

Tabel 05 :

Tolok ukur uji kualitas sagon tepung talas kimpul dengan substitusi $\mathbf{5 0} \%$; $\mathbf{5 0} \%$.

\begin{tabular}{clll}
\hline Nilai & Rasa & Warna & Tekstur \\
\hline 3 & $\begin{array}{l}\text { Manis,gurih dan rasa } \\
\text { khas Talas kimpul }\end{array}$ & Putih kecoklatan & Renyah \\
2 & $\begin{array}{l}\text { Manis dan kurang } \\
\text { rasa khas Talas } \\
\text { kimpul Kecoklatan }\end{array}$ & Rapuh \\
1 & $\begin{array}{l}\text { Tidak manis dan tidak } \\
\text { berasa khas Talas } \\
\text { kimpul }\end{array}$ & $\begin{array}{l}\text { Warna gosong coklat } \\
\text { ataun }\end{array}$ & Kering \\
\hline
\end{tabular}

Sumber. Marisa Ika Ratnawati (2012)

Tujuan dari penelitian ini adalah untuk mengetahui kualitas sagon dengan mengunakan teung talas kimpul dilihat dari aspek rasa, warna, dan tekstu.Teknik analisis data yang digunakan adalah teknik deskriptif kuantitatif. Desakriptif kuantitatif adalah metode pengolahan data yang dilakukan dengan cara menyusun sistematis dalam angka-angka dan suatu persentase mengenai suatu objek yang diteliti sehingga memperoleh kesimpulan umum (Agung,1999). Setelah dianalisi data 
maka diperoleh kesimpulan pada ui kualitas sagon tepung talas kimpul maka ditentukan hasil dengan menggunakan Rumus yaitu:

Keterangan:

$$
\text { Mean }(\bar{X})=\frac{\sum X}{N}
$$

$$
\begin{aligned}
\bar{X} & =\text { Mean (rata-rata) } \\
\Sigma \mathrm{x} & =\text { Jumlah skor masing }- \text { masing } \\
\mathrm{N} & \text { (rasa, warma, tekstur) }
\end{aligned}
$$$$
\text { (Koyan,2011) }
$$

Rumus mengunakan pedoman konversi skala 3 :

Rumus pedoman konversi skala 3 (Tiga):

$$
\begin{aligned}
& \mathrm{M}+1 \mathrm{SD} \longrightarrow \mathrm{M}+3 \mathrm{SD} \text { (Baik) } \\
& \mathrm{M}-1 \mathrm{SD} \longrightarrow \mathrm{M}+1 \mathrm{SD} \text { (Cukup) } \\
& \mathrm{M}-3 \mathrm{SD} \longrightarrow \mathrm{M}-1 \mathrm{SD} \text { (Buruk) }
\end{aligned}
$$

\section{Keterangan:}

$M=$ Mean atau rata - rata

$\mathrm{SD}=$ Standar Deviasi

Rumus mencari Mean dan Standar Deviasi: $\mathrm{M}=$ Mean atau rata -rata yang dicari dengan
rumus:

$\mathrm{M}=\mathrm{x}$ (skor maksimum + skor minimum)

$\mathrm{SD}=$ Standar Deviasi yang dicari dengan rumus:

$\mathrm{SD}=\mathrm{x}($ skor maksimum - skor minimum $)$

Skor Maksimum = 3

Skor Minimum = 1

Berdasarkan rumus diatas, maka data yang terkumpul akan dicari konvensinya.

Sehingga mendapatkan hasil sebagai berikut:

$\mathrm{M}=\mathrm{x}(3+1)$

$M=2$

$\mathrm{SD}=\mathrm{x}(3-1)$

$S D=0,33$
Acuan yang digunakan untuk menentukan kualitas kue kering sagon tepung talas kimpul adalah

Baik : $2,33 \rightarrow 3,00$

Cukup : $1,67 \rightarrow 2,33$

Kurang: $1,00 \longrightarrow 1,67$

\section{HASIL DAN PEMBAHASAN HASIL}

Penelitian ini dilakukan pada tanggal 9 Oktober 2017. Hasil penelitian ini kualitas adalah tepung talas kimpul yang diolah menjadi kue kering sagon dilihat dari aspek rasa,warna, dan tekstur. Pengumpulan data mengunakan lembar observasi berupa lembar uji kualitas terhadap 25 orang panelis terlatih yang terdiri dari Dosen dan Laboran PKK Tata Boga Undiksha, Guru Tata Boga

di SMK N 1 Seririt, Guru Tata Boga SMK Pariwisata Triatmajaya Singaraja, serta mahasiswa PKK program studi Tata Boga Undiksha. Data yang dioeroleh dianalisis mengunakan teknik analisis deskriptif kuantitatif, sehingga diperoleh kesimpulan terhadap kualitas sagon dengan mengunakan formulasi $50 \%$ tepung talas dan $50 \%$ tepung ketan yang dilihat dari aspek rasa, warna, dan tekstur dengan menggunakan kriteria baik,cukup,dan kurang.

Proses pengolahan kue kering sagon dengan formulasi $50 \%$ tepung talas kimpul : $50 \%$ tepung ketan, dengan menggunakan resep dasar kue kering sagon tepung ketan,dengan bahan-bahan sebagai berikut: $100 \mathrm{gr}$ tepung ketan, $100 \mathrm{gr}$ tepung talas kimpul, $100 \mathrm{gr}$ gula pasir, $60 \mathrm{ml}$ air, 1/2sdt garam, 300gr kelapa parut. Dengan menggunakan peralatan yang bersih dan kering tidak terkontaminasi bakteri atau debu. Peralatan yang digunakan dalam proses pengolahan kue kering sagon seperti:loyang, piring, waskom, ayakan tepung, wajan, sutil, kompor, timbangan, gelas ukur, panci kecil, parutan kelapa.dan cetakan. Tahap pembuatan dengan melakukan pelarutan gula, menyanggrai kelapa dan tepung, selanjutnya menyampurkan seluruh bahan 
diaduk rata yang kemudian dicetak dan dioven. Hasil uji kualitas dengan mengunakan tepung talas dari aspek rasa,warna dan tekstur dapat dilihat dari hasil tabulasi data yang kemudian disajikan dengan perhitungan dan disajikan dengan hasil uji kualitas sagon tepung talas kimpul dan diagram batang.

Tabel 06:

Hasil uji kualitas kue kering sagon tepung talas kimpul

\begin{tabular}{|c|c|c|}
\hline Aspek yang dinilai & Hasil & Kategori \\
\hline Rasa & 2.76 & Baik \\
\hline Warna & 2.68 & Baik \\
\hline Tekstur & 2.56 & Baik \\
\hline $\begin{array}{l}\text { 3erdasarkan hasil } \\
\text { ing sagon dengan } \\
\text { a) kualitas sagon } \\
\text { pek rasa berada p } \\
\text { suai dengan tolor } \\
\text { dan gurih, akan }\end{array}$ & $\begin{array}{l}\text { i kualitas } \\
\text { Jung talas } \\
\text { Jung talas } \\
\text { a katagori } \\
\text { ikur yaitu } \\
\text { tapi rasa }\end{array}$ & $\begin{array}{l}\text { tekstur berada pada katagor } \\
\text { sesuai dengan tolok ukur } \\
\text { pengunaan kelapa } \\
\text { mempengaruhi tekstur dari } \\
\text { Dapat dilihat pada diagram } \\
\text { berikut: }\end{array}$ \\
\hline
\end{tabular}

kue kering sagon dengan tepung talas kimpul. a) kualitas sagon tepung talas dari aspek rasa berada pada katagori baik sesuai dengan tolok ukur yaitu manis dan gurih, akan tetapi rasa agak keras pengaruh dari tepung talas, kelapa juga berpengaruh terhadap rasa dari sagon, b) kualitas sagon tepung talas dari aspek warna berada pada katagori baik sesuai dengan tolok ukur yaitu putih kecoklatan, hal ini dipengaruhi oleh warna dasar dari tepung talas kimpul sehingga terlihat perbdaan antara sagon tepung ketang dengan sagon yang terbuat dari tepung talas c) kualitas sagon tepung talas dari aspek

\section{PEMBAHASAN}

Kualitas Rasa,Warna, dan Tekstur Kue Kering Sagon Tepung Talas Kimpul $\mathbf{5 0} \%$ dengan $\mathbf{5 0} \%$ Tepung Ketan.

\section{Rasa}

Berdasarkan hasil uji dari 25 orang panelis yang dilakukan, diketahui bahwa rasa kue kering sagon tepung talas dengan substitusi $50 \%$ tepung talas

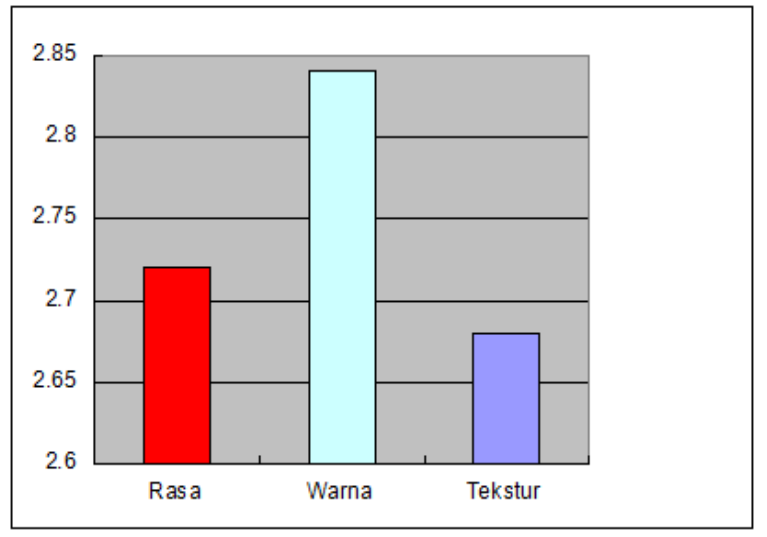

dengan $50 \%$ tepung ketan dengan skor 2,76 yang masuk dalam katagori baik sesuai dengan karakteristik manis dan gurih. Pengunaan tepung talas sangat mempengaruhi rasa dari sagon. Beberapa panelis menyatakan bahwa: Rasa Sagon tepung talas lebih asin. Hal ini disebabkan oleh pengaruh garam ketika melakukan perendaman talas mengunakan larutan 
garam untuk menghilangkan asam oksalat yang terkandung pada talas. sehingga disarankan untuk mengurangi pengunaan garam dalam adonan sagon. Selain itu pengunaan kelapa juga mempengaruhi kualitas rasa dari sagon karena rasa gurih yang dihasilkan dari kelapa dapat mempengaruhi kualitas dari sagon.

\section{Warna}

Berdasarkan hasil uji panelis warna kue kering sagon substitusi dari tepung ketan dengan tepung talas kimpul dengan skor 2,68 berada pada katagori baik dan sesuai dengan tolok ukur yang ditentukan yaitu putih kecoklatan. Warna putih kecoklatan dihasilkan dari warna asli tepung talas. Beberapa panelis menyatakan bahwa: warna dari tepung mempengaruhi warna dari sagon dengan warna putih kecoklatan yang dipengaruhi oleh warna dari tepung talas.

\section{Tekstur}

Berdasarkan hasil uji 25 orang panelis ahli tekstur dari kue kering sagon substitusi tepung talas kimpul denga tepung ketan dengan skor 2,56 berada pada katagori baik dan sesuai dengan tolak ukur dengan tekstur renyah dan kering. Beberapa panelis menyatakan bahwa: tekstur dari sagon tepung talas lebih rapuh dari tepung ketan hal ini disebabkan oleh kandungan yang terdapat pada tepung talas, tekstur tepung talas kimpul yang kering juga dapat mempengaruhi tekstur dari sagon sehingga tekstur dari sagon tepung talas kimpul lebih rapuh dan kasar dibandingkan tepung ketan yang lebih basah, karena kandungan abu yang tinggi terdapat pada tepung talas.

\section{SIMPULAN DAN SARAN SIMPULAN}

Simpulan dari penelitian ini adalah Kualitas Substitusi kue kering sagon tepung talas kimpul dengan tepung ketan dari aspek rasa, warna, dan aroma berada pada katagori baik, masing - masing aspek memiliki skor yang berbeda. Untuk rasa memiliki skor sebesar 2,76 sesuai dengan tolok ukurnya yang memiliki rasa manis dan gurih yang berasal dari gula dan kelapa yang disangrai, untuk warna memiliki skor sebesar 2,68 sesuai dengan tolok ukur warna kue kering sagon dengan warna putih kecoklatan yang berasal dari warna tepung talas, sedangkan tekstur memiliki skor sebesar 2,56 sesuai dengan tolok ukur sagon yang memiliki tekstur renyah dan kering.

\section{SARAN}

1. Rasa dari sagon harus disesuaikan dengan bahan, sehingga sesuai dengan karakteristik tolok ukur yang dibuat.

2. Tekstur yang diperoleh dari sagon juga harus disesuaikna dengan penggunaan kelapa yang dapat mempengaruhi kualitas tekstur sagon.

3. Tepung talas kimpul merupakan salah satu bahan pangan lokal yang memiliki banyak manfaat, salah satu produk makanan yaitu sagon, untuk peneliti lanjut disarankan untuk menambah keaneka ragaman hasil olahan dari tepung talas kimpul, dan untuk meningkatakan nilai ekonomis dari tepung talas.

\section{DAFTAR RUJUKAN:}

A.A. Gede Agung.1990. Metodelogi Pendelitian Pendidikan. Pengantar Ringkas. Singaraja: Sekolah Tinggi Keguruan dan IImu Pendidikan Singaraja.

Arikunto, Suharsimi. Dasar - Dasar Evaluasi Pendidikan (Edisi Revisi). Jakarta: Bumi Angkasa.

Bramtadares, G. B. 2013. Formulasi Terigu dan Tepung Keladi Pada Pembuatan Roti Tawar. Skripsi (tidak diterbitkan). Jurusan IImu dan Teknologi Pangan. Universitas Udayana Bukit Jimbaran.

Cahya, H. N. 2014. Budidaya dan Cara Olah Talas Untuk Makanan dan 
Jurnal Bosaparis: Pendidikan Kesejahteraan Keluarga

Volume 9, Nomor 2, Juli 2018

Obat. Yogyakarta: Pustaka Baru Press

Koyan, 2011. Asesmen Dalam Pendidikan. Singaraja:Universitas Pendidikan Ganesha

Pratama, I. A., \& Nisa, F. C. (2014). "Formulasi Mie Kering Dengan Substitusi Tepung Kimpul Dan Penambahan Tepung Kacang Hijau". Jurnal Pangan dan Agroindustri. Volume 2, nomor 4 (hlm. 101 - 112). Universitas Brawijaya, Malang. Tersedia pada http://www.jpai.org. (diakses pada tanggal 17 April 2017).

Marisa, Ratnawati.I. 2012. "Pembuatan Kue Sagon Kering".Jurnal Pangan. Universitas Sebelas Maret. Tersedia pada: Perpustakaan.uns.ac.id. diakses pada tanggal 20 Juli 2017.

Purwo Djatmiko, 2014. Kamus Bahasa Indonesia Lengkap.Surabaya: Anugrah

Sarifudin, A., \& Ekafitri, R. 2015. "Karakteristik Sifat Fisiko-Kimia Dan Thermal Serta Penerimaan Organoleptik Kue Sagon Berbasis Tepung Pisang ". Jurnal Penelitian Pascapanen Pertanian. 12(1): 27-37. Pusat Pengembangan Teknologi Tepat Guna. Tersedia pada http://jppp.com. Diakses pada tanggal 17 April 2017.

Suharsimi,A. 2009. Dasar-dasar Evaluasi Pendidikan.Jakarta: PT Bumi Aksara

Unit Layanan Laboratorium Fakultas Teknologi Universitas Udayana.2017
Widayati, E. \& Widya, D. 2007. Aneka Panganan dari Talas. Surabaya: PT Trubus Agrisarana 